\author{
Ahmet Şen \\ Yakup Tomak \\ Başar Erdivanlı \\ Aysel Kurt
}

\title{
Ketiapine Bağlı Gelişen Kardiyak Arrest ve Bilinç Kapanması
}

\author{
Intensive Care Management of a Case of Cardiac \\ Arrest Following Ketiapine Use
}

Geliş Tarihi/Received: 31.08.2012

Kabul Tarihi/Accepted: 13.10.2012

Türk Yoğun Bakım Derneği Dergisi, Galenos Yayınevi tarafından basılmıştır

Journal of the Turkish Society of Intensive Care, published by Galenos Publishing.

ISNN: 1300-5804

Ahmet Şen (凶), Yakup Tomak, Başar Erdivanlı Recep Tayyip Erdoğan Üniversitesi Tıp Fakültesi, Anesteziyoloji ve Reanimasyon Anabilim Dalı, Rize, Türkiye

Aysel Kurt

Recep Tayyip Erdoğan Üniversitesi Tıp Fakültesi, Göğüs Cerrahi Anabilim Dalı, Rize, Türkiye

E-posta: ahmetsenau@gmail.com

ÖZET Ketiapin depresyon, bipolar bozukluk ve şizofreni tedavisinde yaygın olarak kullanılan bir antipsikotiktir. Santral sinir sisteminde, dopamin ve serotonin başta olmak üzere pek çok reseptörle etkileşen ketiapin, doza bağımlı olarak somnolans, koma ve hiperglisemi gibi çok farklı yan etkilere yol açabilir. QT uzamasına neden olarak taşikardi başta olmak üzere kardiyak disritmilere ve hatta kardiyak arreste yol açabilir. Histamin reseptörleri üzerindeki antagonizması sonucu bilinç ve solunum depresyonuna neden olarak mekanik ventilatör ihtiyacı yaratabilir. Bu olgu sunumunda, ketiapin kullanımı sonrası koma ve solunum depresyonu geliştiği düşünülen 80 yaşında erkek hastanın yoğun bakım ünitemizdeki takip ve tedavisini tartışmayı amaçladık.

Anahtar Kelimeler: Ketiapin, kardiyak arrest, koma

\begin{abstract}
SUMMARY Quetiapine is an antipsychotic commonly used in treatment of depression, bipolar disorders and schizophrenia. Quetiapine interacts with several receptors present in the central nervous system and therefore may cause diverse side effects like somnolence, coma or hyperglycemia. By prolonging OT interval, quetiapine may predispose the patient to tachycardia and other cardiac dysrhythmias and even cardiac arrest. Due to its antagonism on histaminergic receptors, quetiapine may cause respiratory depression and coma, necessitating mechanical ventilation support. On this paper, we discussed the management of an 80 year old male who is suspected to present with coma following quetiapine administration
\end{abstract}

Key Words: Quetiapine, cardiac arrest, coma
16. Yoğun Bakım Kongresinde "Ketiapine Bağlı Gelişen Kardiyak Arrest ve Bilinç Kapanması" başlığıyla poster olarak sunulmuştur atıır (2). Antipsikotik kullanımı sırasında EKG değişikleri mortalite ve morbidite açısından önemli bir belirleyici olabilir. Epidemiyolojik ve vaka kontrol çalışmaları antipsikotik tedavinin ani ölüm oranlarını artırdığını göstermektedir (3). Mortal seyreden vakalarda sıklıkla kardiyak disritmi ve hipertansiyon öyküsü olduğu gözlenmiştir (4). Atipik antipsikotik olan ketiapin, doza bağımlı olarak taşikardi, somnolans, hiperglisemi, OT uzaması ile kardiyak aritmi ve arreste neden olabilmektedir (5). 
Ketiapin beyinde serotonerjik 5HT1A ve 5HT2A, 5HT2C, $5 H T 7$, dopaminerjik D1 ve D2, histaminerjik $H 1$, adrenerjik $\alpha 1$ ve $\alpha 2$ ve yüksek serum konsantrasyonlarında M1 muskarinik asetilkolin reseptörlerine antagonistik etki gösterir (6). Dolayısıyla klinikte uygulandığı dozlarda, dopamin, serotonin, adrenerjik antagonizma gösteren, önemli bir antikolinerjik yan etkiye neden olmaksızın güçlü bir antihistaminik etki gösteren bir ilaçtır Antipsikotik etkileri 5HT2A ve D2 reseptör antagonizmasına bağlı oluşur Atipik etkilerinin D2 reseptörlerine bağlanmasına bağlı olduğu gösterilmiştir Fakat D2 reseptörlerine geçici olarak ve çok kısa süreyle bağlandığından, nigrostriatal ve tuberoinfundibular yolaklarda dopamin salınımını etkilemediği gösterilmiştir Bu nedenle ekstrapiramidal yan etkiler ve prolaktin salınımında artış görülmemektedir Alfa1 adrenerjik ve $\mathrm{H} 1$ histaminerjik reseptörlere daha uzun süre bağlandığından dolayı, ketiapin uygulaması sonrası sıklıkla hipotansiyon ve sedasyon hali gözlenmektedir (1). Klinik uygulamada, H1 reseptör antagonizmasına bağlı olarak sedasyon riskinin ortostatik hipotansiyondan daha yüksek olduğu gösterilmiştir (7).

Alzheimer hastalığı, kronik obstrüktif akciğer hastalığı $(\mathrm{KOAH})$, hipertansiyon (HT) tanıları olan 80 yaşında erkek hastanın antipsikotik kullanımı sonucu oluşan kardiyak arrest ve sonrasında yoğun bakım ünitesinde (YBÜ) takip ve tedavilerini tartışmayı amaçladık.

\section{Olgu}

Düşme sonucu sol 4-6. kostalarda fraktür + sol pnömotoraks nedeniyle toraks tüpü takılarak göğüs cerrahi servisine yatırılan hastanın kraniyal tomografisinde travmaya bağlı herhangi bir bulguya rastlanmadı. KOAH, Alzheimer hastalığı ve hipertansiyon öyküsü olan hasta düzenli ilaç kullanmamaktaydı. Servisteki takibinde bilinci açık, spontan soluyan hastanın vital bulguları stabil seyretti. Ajitasyon ve kooperasyon güçlüğünden dolayı yatışının 2. gününde psikiyatri kliniği tarafından ketiapin 150 mg tb 1x1 akşam po tedaviye eklendi. Yatışının 3. gününde, ketiapin alımından yaklaşık 1 saat sonra kardiyak arrest gelişmesi üzerine atropin $3 \mathrm{mg}$ iv ve adrenalin $1 \mathrm{mg}$ iv uyguland, ventriküler fibrilasyon gelişen hasta 2 kez $360 \mathrm{~J}$ ile defibrile edilerek sinüs ritminde (140/dk) spontan dolaşım (TA: 80/40 mmHg) sağlandı. Şuuru kapalı, pupilleri middilate, ışık refleksi +/+, spontan solunumu olmayan hasta entübe edilerek $6 \mathrm{l} / \mathrm{dk} \mathrm{O}_{2}$ desteğinde ambulanarak cerrahi YBÜ'ne alındı, SIMV modunda mekanik ventilatöre (MV) bağlandı $\left(\mathrm{FiO}_{2}\right.$ : \%50, TV: $550 \mathrm{ml}$, I/E: 1/2, F: 10/d, PEEP: 5 $\mathrm{cmH}_{2} \mathrm{O}$ ). Nörolojik muayenede pupiller mid-dilate, Işık refleksi +/+, sözel uyaranlara cevap yok, ağrılı uyarana fleksör cevap vardı (Glasgow koma skalası [GKS]: 5). Tansiyon değerlerinin düşük seyretmesi üzerine dopamin infüzyonu $(10 \mathrm{mcg} / \mathrm{kg} / \mathrm{dk})$ başlandı. Inotrop tedavi ve iv hidrasyon sonucu tansiyonu yükselen hastaya perlinganit infüzyonu $(0,5 \mathrm{mcg} / \mathrm{kg} / \mathrm{dk})$ ile antihipertansif tedavi başlandı. Ilk gün deksmedetomidin infüzyonu (0,07 mcg/kg/dk) ile sedatize edildi. Entübasyonun 2. gününde deksmedetomidin infüzyonu kesilen hastada uyanma gözlenmedi (GKS: 5), nazogastrik sonda ile nazoenteral beslenme başlandı. Emboli şüphesi ile çekilen kraniyal ve toraks tomografisinde patoloji saptanmadı. Şuurunda açılma olmayan ve GKS değeri 4'e gerileyen hastanın 7. gününde çekilen kontrol kraniyal tomografisi de normal olarak değerlendirildi. Hastaya 13. gününde KBB kliniği tarafından sedoanaljezi altında cerrahi trakeotomi açıldı. Yatışının 60. gününe dek ASB/CPAP modunda $\left(\mathrm{FiO}_{2}\right.$ : \%30, PEEP: $5 \mathrm{cmH}_{2} \mathrm{O}$, PIP: $12 \mathrm{cmH}_{2} \mathrm{O}$ ) takip edilen hasta bu günden itibaren T-parçası ile $2 \mathrm{l} / \mathrm{dk} \mathrm{O}_{2}$ desteğinde spontan soluyarak takip edildi ve genel cerrahi kliniği tarafından sedoanaljezi altında perkütan endoskopik gastrostomi (PEG) açılarak takibeden günden itibaren enteral beslenmesine devam edildi. Yatışının 70. gününde çoklu organ yetmezliği bulguları gözlenen hastanın idrar çıkışı 0,5 ml/kg/saat'in altına düştü, iv mayi ve inotrop desteğine rağmen tansiyonu düşük seyretti, karaciğer enzimlerinde ve üre, kreatinin değerlerinde yükselme gözlendi. Tüm medikal desteğe rağmen yatışının 72. gününde kardiyak arrest gelişti, resüsitasyona yanıt alınamadı.

\section{Tartışma}

Tıbbi geçmişinde $\mathrm{KOAH}$, kontrolsüz hipertansiyon, atriyal fibrilasyon ve Alzheimer hastalı̆ı mevcut olan olgumuzda, akşam saatlerinde oral ketiapin uygulamasından yaklaşık bir saat sonra sinüzal taşikardiyi takiben kardiyak arrest gelişti.

KOAH mevcut olan hastada, ketiapine bağlı oluşan sedasyon nedeniyle hipoksemi gelişmiş olma intimali vardır. Yaygın kot fraktürüne bağı ağıı ve solunum sıkıntısı da hipoksemiyi kolaylaştırmıştır. Mevcut atriyal fibrilasyon zemininde, ketiapin kardiyak disritmiyi tetiklemiş veya alevlendirmiş olabilir. Hastanın yaşının ileri olması ve aldığı ilaç ile sedasyon düzeyinin artması ortostatik hipotansiyona sebep olmuş veya derinleştirmiş olabilir. Ketiapin tedavisinde ortostatik hipotansiyon ve senkop oluşmaması için, tedaviye düşük dozlarda başlanması ve etkili doza (300-450 mg/gün) dört günde ulaşılması önerilmektedir (8). Ketiapin (100-200 mg/gün) alan yaşlı hastaların \%20'den fazlasında, kalp hızında 20/dk veya daha fazla artma ve sistolik kan basıncında $30 \mathrm{mmHg}$ veya daha fazla düşüş saptanmıştır (9). Çalışmalarda ketiapinin $\alpha 1$-adrenerjik reseptörlere afinitesi sonucu ortostatik hipotansiyon meydana geldiği, H1 reseptör antagonizması sonucu sedasyon ve somnolansın derinleştiği ve buna bağlı olarak sinüs taşikardisi geliştiği belirtilmiştir $(1,10,11)$.

Ketiapin ile en sık gözlenen yan etkiler uykuya eğilim, sersemlik, ağız kuruluğu, kabızlık, karaciğer fonksiyon testlerinde bozulma, dispepsi, kilo alımı ve sık olmamakla birlikte ciddi kardiyak etkiler olarak bildirilmektedir $(12,13)$. Incelenen birçok çalışmada ketiapin ve benzeri antipsikotikler 
yan etki açısından en çok yaşlı hastaları etkilemektedir. Ilaç dozları ve doz artışları bu nedenle yașı hastalarda daha düșük titrelerde olmalıdır (14). Demansı olan yașlı hastaların psikozunda ketiapin kullanıldığında ölüm riskinde artış olabileceği ilacın prospektüs bilgilerinde yer almaktadır. Olgumuz öyküsündeki hastalıkları nedeniyle de düzenli ilaç kullanmamaktaydı. Nörolojik geçmişi tam olarak belli olmayan yaşlı hastalar olgumuzda olduğu gibi latent bir demans potansiyeline sahip olacakları için antipsikotiklerin tüm komplikasyonlarını sergilemeleri mümkündür.

Olgumuzda kardiyak arrest sonrası 3 dakika içinde kardiyopulmoner resüsitasyona yanıt alındı. Spontan solunumu, ışık refleksi ve ağrılı uyaranlara yanıtı olan hastada uzamış arteriyel hipoksemiye bağlı serebral hasar intimali düşüktür.
Hemodinaminin stabil seyretmesine rağmen nörolojik bulgularda ve bilinç durumunda hiçbir ilerleme kaydedilmedi.

Tüm bu bilgilerden anlașılacağı gibi antipsikotiklerin kullanımı sırasında oluşabilecek ciddi kardiyak etkiler hekimler tarafından iyi bilinmeli ve tanınmalıdır. Çünkü oluşabilecek kardiyak etkilerin tanınması, hem riskli hastaların belirlenmesi hem de olası olumsuzlukların önlenmesi için önemlidir (15).

Olgumuzda, pulmoner emboli, aritmi ve hipoksi gibi nedenler ekarte edilmeye çalışılmış, neticede ketiapine bağlı kardiyak arrest gelişmiş olabileceği düşünülmüştür. Sonuç olarak, psikofarmakolojik ajanlara bağlı kardiyak arrest gelişebileceği, tedavi öncesi genel risk değerlendirmesinde yaş, ilave nörolojik hastalık, ilaç dozu ve tedavideki takip metodunun önemli olduğunu düşünmekteyiz.

\section{Kaynaklar}

1. Balit CR, Isbister GK, Hackett LP, Whyte IM. Quetiapine Poisoning: A Case Series. Ann Emerr Med 2003;42:751-8.

2. Young $A C$, Kleinschmidt $K C$, Wax PM Late-Onset Seizures Associated with Quetiapine Poisoning. J Med Toxicol 2009;5:24-6.

3. Straus SM, Bleumink GS, Dieleman JP, van der Lei J, 't Jong GW, Kingma JH, et al. Antipsychotics and the risk of sudden cardiac death. Arch Intern Med 2004;164:1293-7.

4. Fernandes PP, Marcil WA. Death associated with quetiapine overdose. Am J Psychiatry 2002;159:2114.

5. Hunfeld NGM, Westerman EM, Boswijk DJ, Haas JAM, PuttenMJAM, Touw DJ Quetiapine in overdosage: a clinical and pharmokinetic analysis of 14 cases. Ther Drug Monit 2006;28:185-9.
6. Ngo A, Ciranni M, Olson KR. Acute quetiapine overdose in adults: A 5-year Retro spective case ceries. Ann Emerr Med 2008:52:541-7.

7. Pollack PT, Zbuk K. Quetiapine Fumarate overdose: Clinical and pharmacokinetic lessons from extreme conditions. Clin Pharmacol Ther 2000;68:92-7.

8. Dev V, Raniwalla J. Quetiapine: a review of its safety in the management of schizophrenia. Drug Saf 2000;23:295-307.

9. Garver DL. Review of quetiapine side effects. J Clin Psychiatry 2000;61(Suppl 8):31-3.

10. Gajwani P, Pozuelo L, Tesar GE. QT interval prolongation associated with quatiapine overdose. Psychosomatics 2000:41:63-5.

11. Müller $C$, Reuter H, Dohmen $C$. Intoxication after extreme oral overdose of quetiapine to attempt suicide: pharmacological concerns of side effects. Case Report Med 2009;2009:371698.
12. Memik NC, Tural U, Onder ME. Ketiapin ile ilişkili olan sinüs taşikardisi. Psikiyatri Psikoloji Psikofarmakoloji (3P) Dergisi 2003;11:235-9

13. Saka MC, Can S, Ozguven HD, Atbaşoğlu EC. Antipsikotik Ilacların Yan Etkileri. Turkiye Klinikleri Dahili Tıp Bilimleri Dergisi Psikiyatri 2005;1:58-66.

14. Miodownik C, LernerV. Quetiapine: efficacy, tolerability and safety in schizophrenia. Expert Rev Neurother 2006;6:983-92

15. Hocaoğlu Ç, Hıdıroğlu H, Kandemir G. Ketiapin kullanımı sırasında ortaya çıkan sinüs taşikardisi: Üç olgu sunumu. Klinik Psikofarmakoloji Bülteni, Cilt: 19, Sayı: 1, 2009 / Bulletin of Clinical Psychopharmacology, Vol: 19, N:1,2009 